\title{
The Relationship between Internal and External Resources, Coping Strategies, Post-Traumatic Symptoms, and Death-Anxiety of Round-the-Clock Paid Philippine Immigrants and Local Workers Taking Care for the Elderly during and after the Gaza War
}

\author{
Pnina Ron \\ School of Social Work, University of Haifa, Mount Carmel, Haifa, Israel \\ Email: pitzyron@research.haifa.ac.il
}

How to cite this paper: Ron, P. (2020). The Relationship between Internal and External Resources, Coping Strategies, Post-Traumatic Symptoms, and Death-Anxiety of Round-theClock Paid Philippine Immigrants and Local Workers Taking Care for the Elderly during and after the Gaza War. Psychology, 11, 606-623.

https://doi.org/10.4236/psych.2020.114041

Received: February 23, 2020

Accepted: April 24, 2020

Published: April 27, 2020

Copyright $\odot 2020$ by author(s) and Scientific Research Publishing Inc. This work is licensed under the Creative Commons Attribution International License (CC BY 4.0).

http://creativecommons.org/licenses/by/4.0/

\begin{abstract}
Objectives: The study examined the relationship between internal resources (sense of mastery and self-esteem), social support, coping strategies (problem-focused, emotion-focused and avoidance) and the post-traumatic symptoms and death anxiety of Philippine work immigrants and local workers taking care for the elderly after Gaza War. Methods: A self-reported questioner of a snow-ball sample of 147 immigrants' workers and 126 Israeli local workers was collected from work agencies in Southern Israel. The study participants agreed to undergo assessments of their post-traumatic symptoms (PTS) and death anxiety levels immediately during and after the Gaza war and, their levels of internal resources and social support.
\end{abstract}

Keywords

Post-Traumatic Symptoms, Work-around-Clock Pay-Job, Internal

Resources, Coping Strategies, Social Support

\section{Introduction}

Studies conducted with the immediate victims of events such wars and Military operations, i.e., general population, survivors, witnesses, and/or close relatives of 
those who were injured or killed during those events, confirm that these individuals are at high risk of suffering distress, acute stress disorder etc., as a reaction to the traumatic event (Saakvitne, 2002; Nuttman-Shwartz \& Dekel, 2007; Ron, 2015a; Gil, Weinberg, Shamai, Ron, Harel, \& Or-Chen, 2015). The symptoms of distress include anxiety, repeated thoughts regarding the event, psychological symptoms, depression and problems in daily functioning (Cohen, 2008; Fullerton, Ursano \& Wang, 2004; Ron, 2019). In severe cases, such a distress reaction can result in varying severity levels of posttraumatic stress disorder (PTSD) (Gidron, 2002; Shalev, Tuval-Mashiach, Frenkiel-Fishman, Hadar, \& Eth, 2006), and death anxiety levels (Ron, 2019).

\section{Literature Review}

Nursing and nursing assistance are considered helping professions that entail a very high-risk of secondary traumatization in addition to their personal distress caused by war or military operation. Among the reasons is that those occupations are very much a client-oriented profession, most of those workers are women and are involved in complex life-and-death situations (Ron \& Shamai, 2013). Among pra-professional such nursing-assistance workers who tack care for the elderly, the symptoms increase much quicker and stronger than among nurses. In fact, the around clock elderly caring is considered as the most substitutional occupation in Israel by rote (Ron \& Lowenstein, 1997; Ron, 2008) and much higher in times of war (Ron, 2015b).

Most Philippine work immigrants' women as well as the local workers taking care of the elderly, have unmediated contact with the elderly people, who may get heart by missiles or bombs as well as those women themselves. The Philippine caregivers engage with the elderly people and occasionally with their families within a few days after their arrival to the elderly people's homes; they live together and share the same household (most of the time without any shelters within the house) and destiny regarding the national and personal safety (Ron, 2015b). The local workers case is somewhat deferent. For example, the local workers have their own supportive families and friends in Israel; they are familiar with the Israeli-Palestinian conflict leading to recurring military operations and how to behave during those events; they speak the language and know the costumes etc.

While due to the frequency of national terror attacks and military operations, most of the medical services providers and professional staff are already organized to function and have developed operational procedures for such situations, for the immigrants' workers it is all new, unfamiliar and frighten situation. Moreover, at the last decades an increasing attention was given to the impact of this tasks on the professional staff such rescue forces, nurses, social workers etc. (Adams, Figley, \& Boscarino, 2008; Ron \& Shamai, 2013) and a very little attention has been given to the work immigrants and the local workers taking care for the elderly. Terms such as secondary trauma, compassion fatigue, and helping 
the helper, are commonly used, suggesting that there is broad recognition of the need to help the professionals but less common regarding volunteers or local and work immigrants' workers including those who take care for the elderly (Ron \& Shamai, 2011).

The term fear of dying refers to the fear of undergoing a violent or painful death. One factor studied in relation to death anxiety is the study which examined the factor of gender, showed that women displayed higher levels of death anxiety than did men (Ron, 2011; Dadfar, Lester, Abdel-Khalek, \& Ron, 2018).

High levels of death anxiety were reported by the Philippine work immigrants' women in Ron's study (2015a) and were related to their experiences during military events. It is likely that people who find themselves in areas in which there are life-threatening events will begin to fear for their lives. It is also likely that the fear experienced by these people will intensify if they are responsible for the lives and welfare of their elderly patients and their own family members (Kelly, 2007).

In this context, the ability to withstand extreme traumatic events such as exposure to war may largely depend on the individual's predisposing vulnerability and internal and external resources. Research literature has demonstrated that one of the most important external resources for coping and adjustment is social support (Hobfoll, Canetti-Nisim, Johnson, Palmieri, Varley, \& Galea, 2008). Social support refers to perceived assistance provided by other persons, such as emotional, informational, and tangible assistance. It is a primary interpersonal resource that has been consistently found to be associated with psychological well-being in times of stress (Norris, 1992), and is generally considered to be a protective factor for individuals who experienced a disaster (Norris, Friedman, Watson, Byrne, Diaz, \& Kaniasty, 2002), terror attack (Hobfoll, et al., 2008; Weinberg et al., 2012), or other potentially life-threatening situations (e.g., Norris et al., 2002; Shalev et al., 2006).

The way how civilian adjust to war or military operation is likely to depend on their coping strategies both in the behavioral and cognitive ways to deal with the stressful event (Lazarus \& Folkman, 1984). The researchers developed the transactional model, classified coping models by function as a problem-focused (PF) or emotion-focused (EF). The individual deals with the stressful event either with the problem or with its emotional and mental outcomes. Carver, Scheier \& Weintraub (1989) amplified the meaning of the coping process and added another coping strategy-avoidance-in which the individual ignores the problem and its emotional consequences. Israeli studies showed that the PF coping strategies were found to be more effective with traumatic events than EF and Avoidance (Ben-Zur, 2008; Weinberg, Harel, Shamai, Or-Chen, Ron, \& Gil, 2017; Weinberg, 2017).

Internal resources that have found to be related to coping with stressful situations such war are self-esteem and sense of mastery (Ron, 2015a). Studies showed a positive correlation between one's levels of sense of mastery and self-esteem and mental health and an inverse correlation between low levels of 
those two variables and emotional distress and anxiety (Greenberg et al., 1992; Sumer, Karanci, Berument, \& Gunes, 2005). In addition, it has been claimed that an individual's self-esteem in terms of one's ability to cope with stress is a factor that affects the development of post traumatic reactions and general mental distress (Benight \& Harper, 2002).

The main goal of the study was to examine the relationships between internal and external resources, coping strategies according to the stress model and the Philippine workers in comparison to the local workers' post-traumatic symptoms and death anxiety.

Based on the literature review, the research hypotheses were established on a model which currently was used twice: The first time: the coping with stress model (Lazarus \& Folkman, 1984), where the Philippine workers participant's research variables were examined in relation to post-traumatic symptoms and death anxiety. The second time: the same examination among the local workers participants.

The research hypotheses were that 1) A relationship will be found between external (social support) resources, and reduction of the PTS and death anxiety among the Philippine workers (G1); 2) A relationship will be found between internal resources (self-esteem and sense of mastery) and reduction of the PTS and death anxiety among the local workers (G2);3) The tendency to use problem-focused coping strategies will reduce the PTS and death anxiety among the local workers (G2);4) The tendency to use emotion-focused coping strategies will reduce the post-traumatic symptoms and death anxiety among the Philippine workers (G1).

\section{Method}

\subsection{Sample and Sampling}

The data in the current study is based on the Philippine workers and the local workers taking care of the elderly after the Gaza-war (Summer 2016). A Snow-ball sample consisted of 147 Philippine workers and 126 Israeli residents who were within the rocket range. The sample included workers from the southern region of Israel. At the time, there were about 20,000 work immigrants in Israel, most of them from the Philippines. That is why we choose only Philippine migrant care workers. The local workers were also from the southern region of Israel. From the two groups of workers, we randomly chose four agencies that employed both local Israelis and Philippine migrant care workers for the elderly. We contacted the directors of the sampled employments agencies directly, explained the goal of the study, and asked for their cooperation in distributing the questionnaires to their employers' e. g. the Philippine migrant and the local care workers who were in Israel during and after the Gaza war. This part of sampling request has changed the sample to a snowball sample because the employees asked the Philippine migrant care workers which they knew to ask their

friends if they were also in Israel during the Gaza war. The questionnaires were 
sent by mail to each of the agencies and were mailed back to us. Of a total of more than 300 questionnaires that were sent out to the group of workers, 147 (about 24\%) questionnaires were returned. Most of the Philippine workers were living in the elderly people homes and the local workers were living either in their own homes (working in two shifts with the elderly) or in the elderly people homes.

The sample characteristics of the study participants are shown in Table 1.

Table 1. Demographic characteristics and intra-personal variables of the Philippine work immigrants and the local workers.

\begin{tabular}{|c|c|c|c|c|}
\hline \multirow[t]{2}{*}{ Characteristics } & \multicolumn{2}{|c|}{$\begin{array}{l}\text { Philippine work } \\
\text { immigrants }(G 1)(N=147)\end{array}$} & \multicolumn{2}{|c|}{$\begin{array}{l}\text { Local workers }(\mathrm{G} 2) \\
(\mathrm{N}=126)\end{array}$} \\
\hline & $\mathbf{N}$ & $\%$ & $\mathbf{N}$ & $\%$ \\
\hline \multicolumn{5}{|l|}{ Family status } \\
\hline Married & 56 & 38 & 75 & 60 \\
\hline Unmarried & 91 & 62 & 40 & 51 \\
\hline \multicolumn{5}{|l|}{ Children } \\
\hline Have children here & 34 & 23 & 117 & 93 \\
\hline Have children abroad & 82 & 56 & 6 & 5 \\
\hline Don't have children & 31 & 21 & 3 & 2 \\
\hline \multicolumn{5}{|l|}{ Education } \\
\hline Elementary school & 74 & 50 & 6 & 5 \\
\hline High school & 66 & 49 & 93 & 73 \\
\hline College & 7 & 1 & 20 & 16 \\
\hline Higher education & - & - & 7 & 6 \\
\hline \multicolumn{5}{|l|}{ Personal exposure to } \\
\hline \multicolumn{5}{|l|}{ Military operations } \\
\hline Yes & 84 & 56 & 126 & 100 \\
\hline \multirow[t]{2}{*}{ No } & 63 & 44 & - & - \\
\hline & $\mathbf{M}$ & SD & $\mathbf{M}$ & $\mathrm{SD}$ \\
\hline Age (in years) & 38.6 & 5.17 & 49.12 & 4.78 \\
\hline \multicolumn{5}{|l|}{ Duration in Israel } \\
\hline (in years) (7 women) & 1.3 & 3.9 & 24.32 & 6.11 \\
\hline Born in Israel (No.) & - & - & - & - \\
\hline Professional experience (in years) & 13.7 & 3.0 & 6.04 & 5.5 \\
\hline Social support & 4.7 & 0.86 & 1.33 & 3.27 \\
\hline Sense of mastery & 4.0 & 1.14 & 1.0 & 3.02 \\
\hline Self-esteem & 3.88 & 0.92 & 4.12 & 0.67 \\
\hline Post-traumatic symptoms & 2.02 & 0.39 & 1.74 & 0.91 \\
\hline Death anxiety & 3.96 & 0.33 & 2.88 & 0.60 \\
\hline \multicolumn{5}{|l|}{ Coping strategies } \\
\hline Problem-focused & 2.00 & 0.50 & 2.82 & 0.10 \\
\hline Emotion-focused & 3.14 & 0.16 & 1.77 & 0.63 \\
\hline Avoidance & 2.92 & 0.24 & 0.90 & 0.47 \\
\hline
\end{tabular}


As the table shows, all participants were women in average age of was 42.2 $(S D=3.74)$ while the local workers average age was about 10 years older. Most of local workers were married (60\%) in comparison to the Philippine workers (38\%), and the majority had children in Israel (about 93\%). Most of the Philippine workers children are in the Philippines (56\%). All local workers experienced military operation before and among the Philippine workers only 56\% have experienced any kind of military operation before.

\subsection{Measures}

All of the study variables are presented in Table 2.

Table 2. The research's variables measures (tools).

\begin{tabular}{|c|c|c|c|}
\hline Independent variables & Authors names & Tool's name & description \\
\hline $\begin{array}{l}\text { Background } \\
\text { characteristics }\end{array}$ & $\begin{array}{l}\text { The demographic and } \\
\text { work variables were } \\
\text { measured using a } \\
\text { questionnaire created } \\
\text { specifically for the } \\
\text { purposes of the current } \\
\text { study }\end{array}$ & & \\
\hline Social support & $\begin{array}{l}\text { Zimmet, Dahlin, } \\
\text { Zimmet, \& Farley, } \\
\text { (1988) }\end{array}$ & $\begin{array}{l}\text { MSPSS-The } \\
\text { multidimensional } \\
\text { scale of perceived } \\
\text { social support }\end{array}$ & $\begin{array}{l}12 \text { items, } 1-7 \\
\text { reliability }=0.88 \\
\text { Cronbach's alpha }\end{array}$ \\
\hline Sense of Mastery & $\begin{array}{l}\text { Pearlin, Managhan, } \\
\text { Lieberman, \& Mullan } \\
\text { (1981) }\end{array}$ & $\begin{array}{l}\text { The scale of sense of } \\
\text { mastery }\end{array}$ & $\begin{array}{l}7 \text { items, } 1 \text { - } 5 \\
\text { reliability }=0.81 \\
\text { Cronbach's alpha }\end{array}$ \\
\hline Self-esteem & $\begin{array}{l}\text { Rosenberg Scale of } \\
\text { Self-esteem (1965) }\end{array}$ & $\begin{array}{l}\text { Rosenberg Scale of } \\
\text { Self-esteem }\end{array}$ & $\begin{array}{l}10 \text { items, } 1-5 \\
\text { reliability }=\text { between } \\
0.81 \text { and } 0.90 \\
\text { Cronbach's alpha }\end{array}$ \\
\hline Coping strategies & $\begin{array}{l}\text { Carver, Scheier \& } \\
\text { Weintraub (1989) }\end{array}$ & & $\begin{array}{l}18 \text { items, } 1-5 \\
\text { reliability }=86 \\
\text { (problem-focused), } \\
0.83 \text { emotion-focused) } \\
\text { respectively } \\
\text { Cronbach's alpha. }\end{array}$ \\
\hline $\begin{array}{l}\text { Dependent } \\
\text { variables }\end{array}$ & & & \\
\hline $\begin{array}{l}\text { Post-traumatic } \\
\text { symptoms }\end{array}$ & $\begin{array}{l}\text { Foa, Riggs, Dancu \& } \\
\text { Rothbaum (1993) }\end{array}$ & $\begin{array}{l}\text { The PTS symptoms } \\
\text { Scale-Self-Report } \\
\text { (PTSSS-SR) }\end{array}$ & $\begin{array}{l}17 \text { items, } 0-3 \\
\text { reliability }=0.90 \\
\text { Cronbach's alpha }\end{array}$ \\
\hline Death anxiety & $\begin{array}{l}\text { Carmel and Mutran } \\
\text { (1997) }\end{array}$ & & $\begin{array}{l}6 \text { items, } 1-5 \\
\text { reliability }=0.90 \\
\text { Cronbach's alpha } \\
0.80\end{array}$ \\
\hline
\end{tabular}




\subsection{Procedure}

The study was approved by the University of Haifa Ethics Committee, ensuring privacy and confidentiality.

At the time the study was conducted, more than 25,000 work immigrants were living in Israel, most of them from the Philippines. From the Israeli southern area, we randomly chose immigrant workers who were in Israel during the war. This process yielded four agencies that employed both local Israelis and work immigrant caregivers for the elderly. We contacted the directors of the sampled employments agencies directly, explained the goal of the study, and asked for their cooperation in distributing the questionnaires to their employers. The questionnaires were sent by mail to each of the agencies and were mailed back to us. Of a total of more than 850 questionnaires that were sent out to the group of workers, 304 questionnaires were returned. Twenty seven of these questionnaires fulfilled by the Philippines workers and four questionnaires fulfilled by the local workers were not included in the final sample, due to missing data. The participants voluntarily completed the questionnaires.

\section{Results}

The respondents in the current study were 147 immigrants' workers (G1) and 126 Israeli local workers (G2). The data analysis and the study hypotheses examination was performed in several stages: In the first stage, the connections between the background characteristics of the participants and the study variables were examined. Pearson's correlation was conducted between the study variables among the study two participants groups, $t$ tests were conducted to examine the differences between the categorical variables differences and, and a Hierarchical regression was conducted to measure the ordinal variables. Table 3 \& Table 4 present the results of the Hierarchical regression

The $\mathrm{t}$-tests between the categorially demographic variables (education, children, family status and personal exposure to military operation) and the study variables were conducted. A strong-statistical different were found between the Philippine work immigrants (G1) and the local workers (G2)' social support variable $(\mathrm{t}=-2.22, p<0.05)$ and the emotional-focused coping strategy $(\mathrm{t}=-3.06$, $p<0.01)$ : The average scores of the Philippine work immigrants were higher, in both variables than the local workers' average scores. A strong-statistical different were found between the existing of children (in Israel or abroad, We ignored the option of: don't have children) and the sense of mastery variable $(\mathrm{t}=3.98, p$ $<0.001)$, the social support variable $(\mathrm{t}=3.90, p<0.01)$, the self-esteem variable $(\mathrm{t}=5.11, p<0.001)$, and the problem-focused coping strategy $(\mathrm{t}=4.26, p<$ $0.05)$ : The average scores of those participants who have their children near them were higher, in all four variables, than those participants whose children were abroad. The average score of the PTS variable was higher among those participants whose children were far away from them than among the participants with their children nearby. 
Examination of the differences between participants who were exposure in the past to any kind of military operation and those who did not and the other study variables, showed statistically strong differences: The sense of mastery variable's score among participants who were experienced previous military operation was higher than those who did not $(\mathrm{t}=3.14, p<0.01)$. The same tendency was found regarding the self-esteem variable $(\mathrm{t}=2.79, p<0.01)$, and the problem-focus coping strategy $(\mathrm{t}=4.05, p<0.05)$. An opposite tendency was found regarding the death anxiety variable $(\mathrm{t}=-2.87, p<0.05)$, the PTS variable $(\mathrm{t}=-4.31, p<$ $0.05)$ and, the avoidance coping strategy $(\mathrm{t}=2.16, p<0.01)$. Hence: The less exposure is, the higher the average scores of death anxiety, PTS and avoidance coping strategy are. Other study's variables were not found to be in statistical differences between them.

Table 3. Hierarchical regression for the dependent variables: PTS and death anxiety among the Philippine work immigrants (G1).

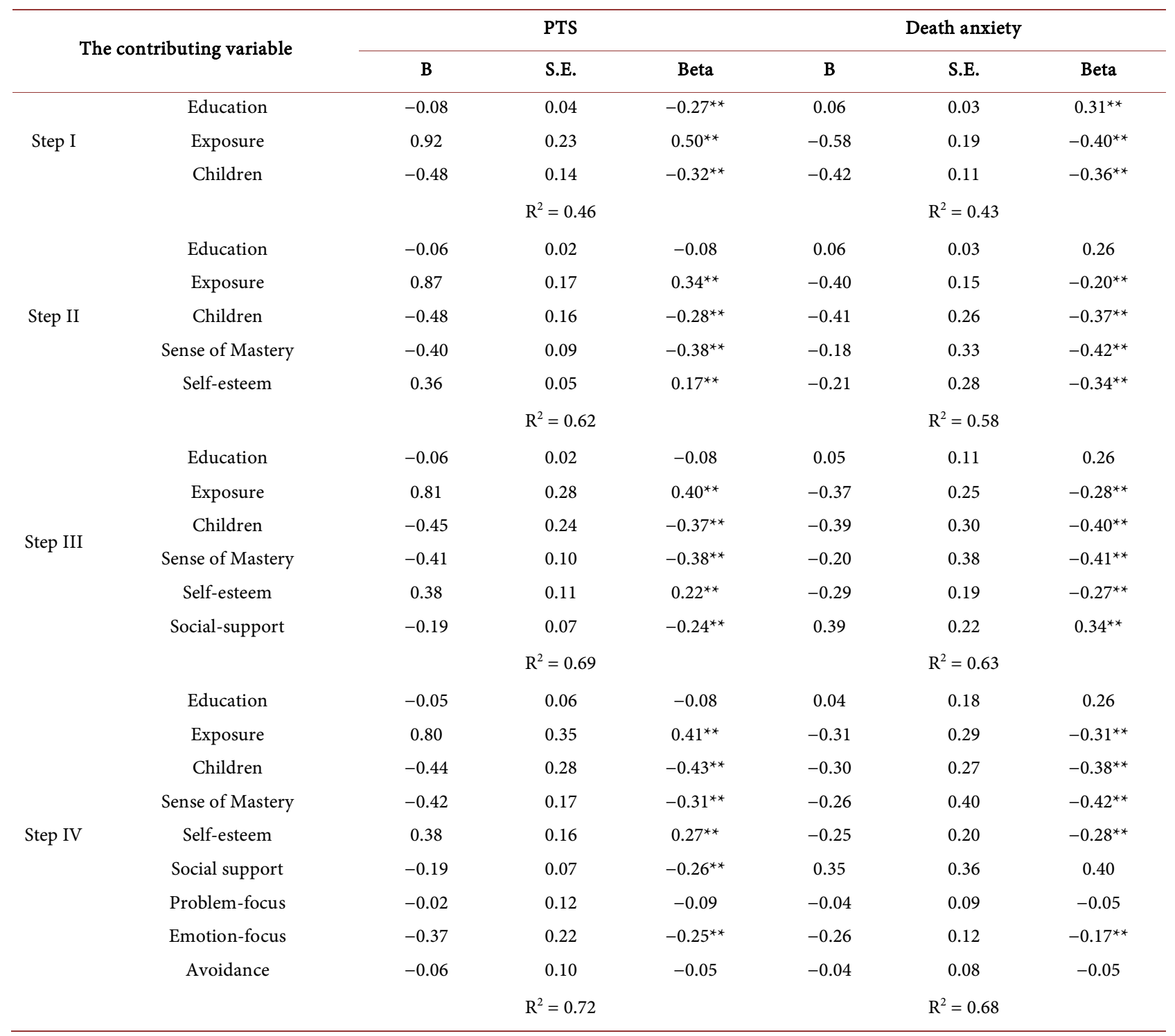

${ }^{\star} P<0.05,{ }^{* *} p<0.01$. 
Table 4. Hierarchical regression for the dependent variables: PTS and death anxiety among the local works (G2).

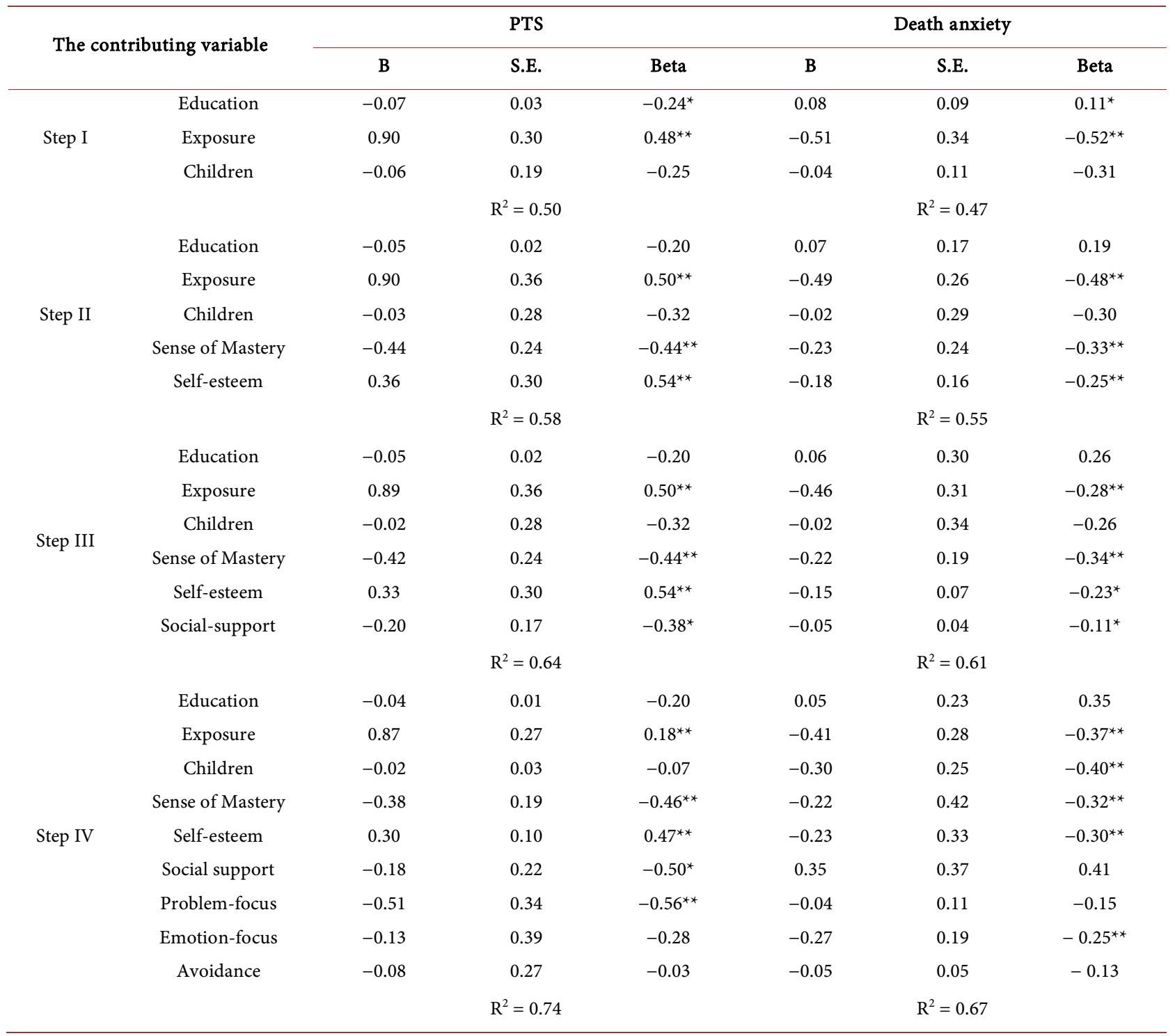

In the second stage, the study hypotheses were measured for the two groups separately: The first one was the coping strategies of the Philippine work immigrants (Group $1=\mathrm{G} 1$ ) in which the study variables were measured according to their PTS and death anxiety variables levels. The second one was the coping strategies of the local workers (Group 2 = G2) in which the study variables were measured according to their PTS and death anxiety variables levels. Those two procedures were measured via Pearson's correlations and a Hierarchical regression was conducted to learn about the study variables contribution to the dependent variables diversity explanation.

Regarding the PTS variable among the Philippine work immigrants, the table shows that the most contributing variables to the explained variance are: the exposure to previous kind of military event, having children, sense of mastery, self-esteem, social support and emotion-focus coping strategy. Regarding the 
death anxiety variable, the table shows that the most contributing variables to the explained variance are: the exposure to previous king of military event, having children, sense of mastery, self-esteem and emotion-focus coping strategy.

Regarding the PTS variable among the local workers, the table shows that the most contributing variables to the explained variance are: the exposure to previous kind of military event, having children, sense of mastery, self-esteem, social support and emotion-focus coping strategy. Regarding the death anxiety variable, the table shows that the most contributing variables to the explained variance are: the exposure to previous king of military event, having children, sense of mastery, self-esteem and emotion-focus coping strategy.

In the third stage of the research data analysis, the structural equation modeling (SEM) was used to examine our hypotheses. Analysis was conducted using AMOS (version 18) (Arbuckle, 2005) using the maximum-likelihood method. Nonsignificant paths were deleted. Moreover, in addition to the overall test of exact fit, the following fit indices were used to evaluate the proposed models: 1) the $\mathrm{X}^{2} / d$ fratio; 2 ) the root mean square error of approximation (RMSEA); 3 ) the comparative fit index (CFI); and 4) the non-normed fit index (NNFI). A model in which $\mathrm{X}^{2} / d f$ was lower or equal than 2, CFI and NNFI were greater than 0.90 and, the RMSEA index was between $0.00-0.09$ (Hu \& Bentler, 1999) was deemed acceptable.

The present two models fit the observed data very well. Model no. $1\left[X^{2}(2)=\right.$ 3.500, $\left.p=0.176, \mathrm{X}^{2} / d f=1.70\right]$ with a good fit measure (NNFI $=0.991, \mathrm{CFI}=$ 0.996 , RMSEA $=0.071$. Model no. $2\left[X^{2}(2)=3.400, p=0.157, X^{2} / d f=1.67\right]$ with a good fit measure $(\mathrm{NNFI}=0.998, \mathrm{CFI}=0.990, \mathrm{RMSEA}=0.077$.

As can be seen in Figure 1, higher levels of exposure to the event, self-esteem and having children in Israel were associated with greater PTS $(p<0.001)$. It is notable that the higher that one has to worry for children in times of war (especially in a foreign country) has a negative effect on developing PTS symptoms. Higher levels of social support, self-esteem and sense of mastery were associated with emotions-focus coping strategies $(p<0.001)$. In addition, higher levels of death anxiety had a positive effect on PTS symptoms $(p=0.002)$. The level of significance for all of the correlations between the presented risk factor in model was $p<0.001$, except for the correlation between the social support and the level of exposure to the event. The model explained 57 percent of the variance in PTS.

Figure 2 shows that higher levels of exposure to the event, were associated with greater death anxiety and problem-focus strategies $(p<0.001)$ while higher levels of self-esteem and sense of mastery were negatively associated with death anxiety $(p<0.001)$.

The level of significance for all of the correlations between the presented risk factor in model was $p<0.001$, except for the correlation between the having children and the level of death anxiety. The model explained 61 percent of the variance in death anxiety. 


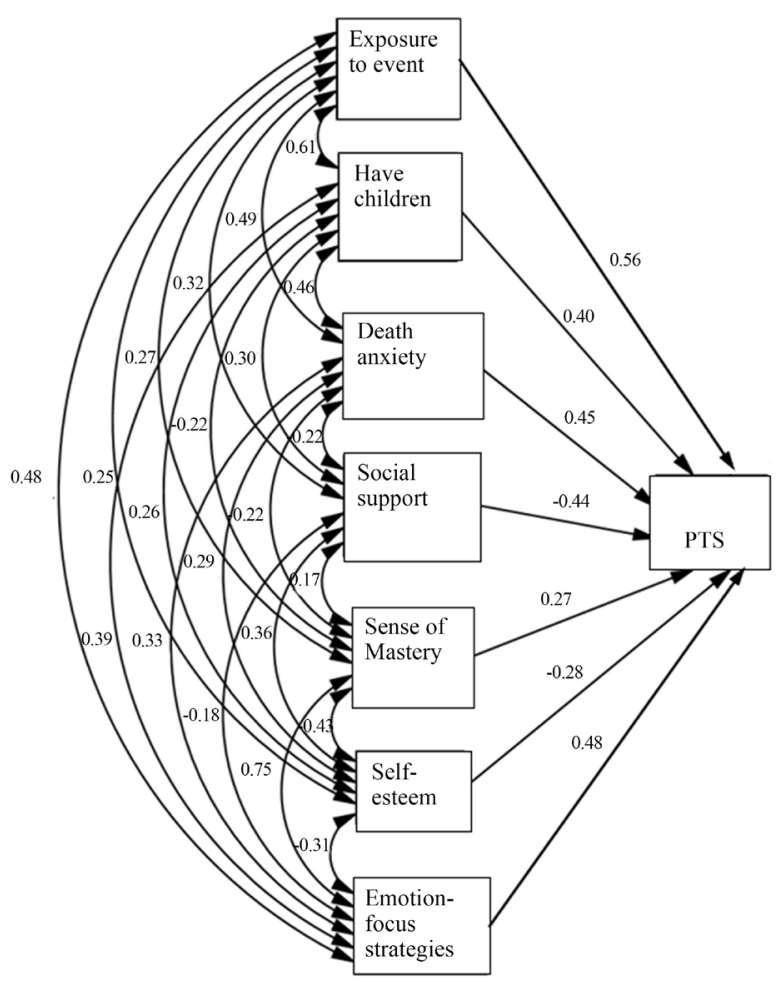

Figure 1. Results of structural equation modeling analysis of the association between having children, exposure to event, death anxiety, self-esteem, social support, sense of mastery, emotion focus strategy and PTS.

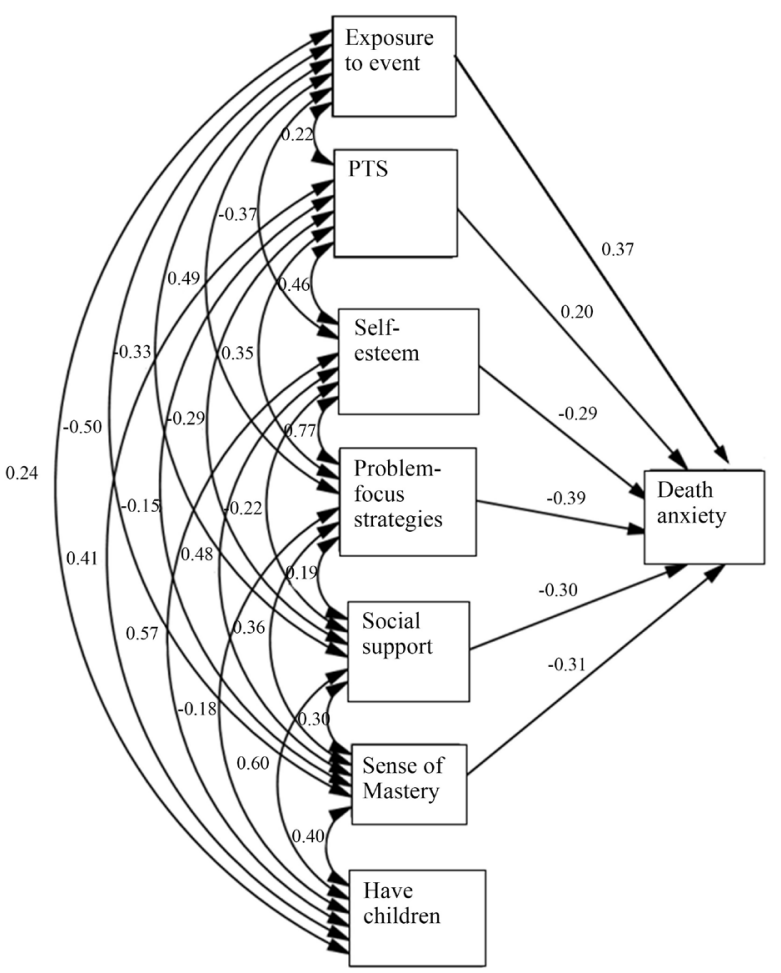

Figure 2. Results of structural equation modeling analysis of the association between having children, exposure to event, PTS, self-esteem, social support, sense of mastery, emotion focus strategy and death anxiety. 
To summarized, the study SEM-Structural Equation Model design (AMOS, version 18) indicated that the Philippine work immigrants (G1) had experienced higher levels of PTS and the local workers (G2) had experienced higher levels of Death anxiety. Internal resources and social support were found to be associated with lower levels of post-traumatic symptoms and higher levels of Death anxiety within the entire sample.

\section{Discussion}

The current study examined the relationship between Internal and external resources, coping strategies, PTS, and Death-anxiety of round-the-clock paid Philippine work immigrants and local workers taking care of the elderly during and after the Gaza War. The exposure of civilians to war and military operations can involve numerous traumatic experiences including distress, separation from family, and even PTS and secondary traumatization (Weinberg, Besser, Campeas, Shvil, \& Neria, 2012; Ron, 2019). The ability to emotionally cope with those events may largely depend on the individual's internal and external resources.

As hypothesized, the current study demonstrated positive connections between the internal resources (sense of mastery, self-esteem) and external resource (social support) and the PTS and death anxiety.

Women, in most of studies that were mentioned in the current study, demonstrate a higher degree of psychological vulnerability, they tend to report stressful situations more frequently, and they develop more incidents of PTS (Ron, 2019; Farhood, Dimassi \& Lehtinen, 2006; Bleich et al., 2003). Because the current study examined only women, we did not emphasize the gender differences and focus on the internal and external resource and, some of the background characteristics such as the socio-cultural differences. Some major differences were found in the current study between the participants' two groups: the first one was the socio-cultural difference (Besser, Neria, \& Haynes, 2009).

Philippine women, care workers for elderly people, undergo a process of adapting to a new culture that is entirely different from the one they come from. Often, the female Philippine migrant care workers opt to leave their family members behind, even when it comes to young children who are still in need of their mother. In addition, the arrangement of living and sharing a household with those workers continuously experience life events which for them are far from simple. In addition, it may be assumed that sharing a routine with elderly people who are prone to experience higher levels of PTS also affects the level of PTS symptoms of the aides who care for them. It became more complicated when those workers have young children with them in Israel (Ayalon, Kaniel, \& Rosenberg, 2008). Ron's study (2015a, 2015b) suggested some explanations for high levels of PTS that were fund among the Philippines workers. For example: most of those workers had never experienced events such as wars or military operations; the fact that their job demanded that they continue functioning in a routine fashion increased the sense of stress, both during the event and after- 
wards; studies have claimed that working with traumatized clients and the exposure to traumatic events often decreases personal stress levels, manifested by PTS symptoms (Dekel \& Hobfoll, 2007; Essar et al., 2008; Ron \& Shamai, 2013; Ron \& Shamai, 2011; Arvay, 2001) or death anxiety. Among the local workers, it seems that the PTS symptoms levels were lower than those among the Philippine workers. The best explanation we can think of regarding this phenomenon is the experience that the local workers have with wars and military events in Israel by the unfortunate nature of life in this country. Growing up and living in Israel miens that one the individual, his/her family and the all community may accept those events on a daily living base. After the individual experience some of those events and is not surprised by them he/she becomes more aware of the vulnerability of life and begins to think about his own private death. The thoughts about the private death are very scary, and the future and what will be after the death is unknown and terrified.

Findings of the current study show differences between the levels of the internal resources (self-esteem and sense of mastery) and the experience of death anxiety. These findings are in line with those presented in the professional literature (Ron, 2015a, 2019; Cicirelli, 2002). Security conditions in Israel entail many dangers, due to the fact that neighboring countries threaten Israel's existence, as evidenced by the relatively frequent terror attacks and the intermittent wars. Consequently, and a second explanation, it is possible that some individuals who do not feel a complete sense of mastery or control over their lives perceive themselves as weak when encountering the source of stress, and believe that in regard to national security, all control is in the hands of fate. Typically, in wartime, when there is a pervasive awareness of the immediacy of death, and civilians have almost no ability to influence the events that unfold, their level of general anxiety increases, as does their level of death anxiety. However, these same feelings of an imminent fate beyond one's control can also have a releasing effect, even if only to a limited extent, freeing the individual from fear of death and resulting in lower levels of death anxiety.

As regards the internal personal variables, findings of the study suggest the existence of an inverse relationship between PTS and death anxiety, on the one hand, and the variables of self-esteem and sense of mastery, on the other hand. These findings support those demonstrated in the literature, which claim that self-esteem and sense of mastery are related to the individual's ability to cope with stress and, thus, these factors impact the development of posttraumatic reactions and general distress. In addition, analysis of the findings of the current study suggests that the sense of mastery variable is the strongest predictor of levels of posttraumatic stress symptoms. This finding suggests that this internal resource serves as a protective factor following exposure to a stressful event, as suggested in the literature, and can help individuals withstand traumatic events.

The circumstances of the current study can explain the negative relationship between death anxiety and self-esteem and sense of mastery. The fact that this relationship was examined in wartime, which in itself is characterized by ex- 
treme lack of control, rather than in routine times, also had an effect on the findings. It may be assumed that for individuals with high levels of self-esteem and sense of mastery, this situation created a cognitive dissonance between their high self-esteem and sense of mastery and the chaotic situation in which they found themselves. This gap between the individual's inner feelings and the external reality can lead to high levels of anxiety, in general, and death anxiety, in particular.

It is important to note that in the majority of studies that deal with death anxiety, this variable is examined in times of routine rather than in times of crisis, emergency, or war. It is possible that the difference between the current study's findings and those of previous studies in the field is related to the fact that in the current study, death anxiety was assessed a short while after the military events and the context of the questionnaires was related to the effect of these events. This explanation should be further examined, in order to understand the ways in which a traumatic event affects the relationship between the variables of self-esteem and sense of mastery and the individual's level of death anxiety.

The findings also show that the external resource-social support was found to be significant and inversely related to the PTS and death anxiety variables' levels. One of the explanations for the PTS' low levels of maybe the migrant workers' support networks which include the social sphere (which includes all migrant workers from the Philippines). These women have established for themselves social frameworks in which they meet on a regular basis, often in apartments that have been converted to churches. On Sundays, their free day, they meet with their friends, attend services related to their faith - which also fortifies them, and share and exchange information about their current situation and their families back home (Ron, 2015b). Another support sphere is the dyadic cycle that is created between the caregiver and the elderly person who is the care recipient. Occasionally this is a triad. It should be noted that the caregiver and the care recipient live together day in and day out in an apartment: they run the household together and share with each other the good days and the bad days. The Philippine migrant care workers understand the co-dependency between them and the elderly person under their care, so that this relationship quickly becomes reciprocal and includes an emotional aspect and active cooperation. Those two explanations are not relevant to the local workers because they do not live with the elderly people on a daily base and they do not need the church to be together; 1) because most of them are Jewish and do not visit the churches and 2) they have their social support within their families, friends, neighbors etc. The third sphere of support is the extended family of the elderly care recipient and the extended family of the caregiver. If the relationship develops in a positive manner, reciprocal interactions help the Philippine migrant care workers, as well as the local workers, avoid PTS. This finding should be further examined in future studies.

\section{Conclusion}

Three factors are important for understanding the situation in Israel: 1) The 
numbers of the elderly population in Israel is increasing and will continue to increase in the future, especially the disabled elderly. 2) There is not enough paraprofessional local men-power to take care of the elderly population. Therefore, Israel needs to rest on work immigrants today as well as in the future. 3) Wars and military operations have been a part of the Israeli population's daily experience over the years. Those three factors are obligating the Israeli authorities to train the paraprofessional work immigrants, to design special emergency health and mental health services and to pay more attention to these important workforces.

\section{Conflicts of Interest}

The author declares no conflicts of interest regarding the publication of this paper.

\section{References}

Adams, R. E., Figley, C. R., \& Boscarino, J. A. (2008). The Compassion Fatigue Scale: Its Use with Social Workers Following Urban Disaster. Research on Social Work Practice, 18, 238-250. https://doi.org/10.1177/1049731507310190

Arbuckle, J. L. (2005). Amos 6.0 Users Guide. Chicago, IL: SPSS Amos Development Corporation.

Arvay, M. J. (2001). Secondary Traumatic Stress among Trauma Counselors: What Does the Research Say? International Journal for the Advancement of Counseling, 23, 283-293. https://doi.org/10.1023/A:1014496419410

Ayalon, L., Kaniel, M., \& Rosenberg, L. (2008). Social Workers' Perspective on Care Arrangements between Vulnerable Elders and Foreign Home Care Workers: Lessons from Israeli/Filipino Caregiving Arrangement. Home Health Care Services, 27, 121-142. https://doi.org/10.1080/01621420802022563

Benight, C. C., \& Harper, M. L. (2002). Coping Self-Efficacy Perceptions as a Mediator between Acute Stress Response and Long-Term Distress Following Natural Disasters. Journal of Traumatic Stress, 15, 177-186. https://doi.org/10.1023/A:1015295025950

Ben-Zur, H. (2008). Personal Resources of Mastery-Optimism, and Communal Support Beliefs, as Predictors of Posttraumatic Stress in Uprooted Israelis. Anxiety, Stress and Coping, 21, 295-307. https://doi.org/10.1080/10615800801956177

Besser, A., Neria, Y., \& Haynes, M. (2009). Adult Attachment, Perceived Stress, and PTSD among Civilians Continuously Exposed to Terrorism in Southern Israel. Personality and Individual Differences, 47, 851-857. https://doi.org/10.1016/j.paid.2009.07.003

Bleich, A., Gelkopf, M., \& Solomon, Z. (2003). Exposure to Terrorism, Stress-Related Mental Health Symptoms, and Coping Behaviors among a Nationally Representative Sample in Israel. Journal of American Medical Association, 290, 612-620. https://doi.org/10.1001/jama.290.5.612

Carmel, S., \& Mutran, E. (1997). Preferences for Different Life-Sustaining Treatments among Elderly Person in Israel. The Journals of Gerontology, Series B: Psychological Sciences and Social Sciences, 52B, S97-S102. https://doi.org/10.1093/geronb/52B.2.S97

Carver, C., Scheier, M., \& Weintraub, J. K. (1989). Assessing Coping Strategies: A Theoretically Based Approach. Journal of Personality and Social Psychology, 56, 267-283. https://doi.org/10.1037/0022-3514.56.2.267 
Cicirelli, V. G. (2002). Fear of Death in Older Adults Predictions from Terror Management Theory. Journals of Gerontology Series B: Psychological Sciences and Social Sciences, 57, 358-366. https://doi.org/10.1093/geronb/57.4.P358

Cohen, M. (2008). Acute Stress Disorder in Older, Middle-Aged and Younger Adults in Reaction to the Second Lebanon War. International Journal of Geriatric Psychiatry, 23, 34-40. https://doi.org/10.1002/gps.1832

Dadfar, M., Lester, D., Abdel-Khalek, A. M., \& Ron, P. (2018). Death Anxiety in Muslim Iranians: The Comparison between Youths, Middle Adults and Late Adults. Illness, Crisis and Loss, 44, 1-16. https://doi.org/10.1177/1054137318790080

Dekel, R., \& Hobfoll, S. E. (2007). The Impact of Resource Loss on Holocaust Survivors Facing War and Terrorism in Israel. Aging \& Mental Health, 11, 159-167. https://doi.org/10.1080/13607860600736141

Essar, N., Ben-Ezra, M., Langer, S., \& Palgi, Y. (2008). Gender Differences in Response to War Stress in Hospital Personnel: Does Profession Matter? A Preliminary Study. The European Journal of Psychiatry, 22, 1622-1637. https://doi.org/10.4321/S0213-61632008000200003

Farhood, L., Dimassi, H., \& Lehtinen, T. (2006). Exposure to War-Related Traumatic Events, Prevalence of PTSD, and General Psychiatric Morbidity in a Civilian Population from Southern Lebanon. Journal of Transcultural Nursing, 17, 333-340. https://doi.org/10.1177/1043659606291549

Foa, E. B., Riggs, D. S., Dancu, C. V., \& Rothbaum, B. O. (1993). Reliability and Validity of a Brief Instrument for Assessing Post-Traumatic Stress Disorder. Journal of Traumatic Stress, 6, 459-473. https://doi.org/10.1002/jts.2490060405

Fullerton, C. S., Ursano, R. J., \& Wang, L. (2004). Acute Stress Disorder, Posttraumatic Stress Disorder and Depression in Disaster or Rescue Workers. The American Journal of Psychiatry, 161, 1370-1376. https://doi.org/10.1176/appi.ajp.161.8.1370

Gidron, Y. (2002). Post-Traumatic Stress Disorder after Terrorist Attacks: A Review. Journal of Nervous and Mental Disease, 190, 118-121. https://doi.org/10.1097/00005053-200202000-00010

Gil, S., Weinberg, M., Shamai, M., Ron, P., Harel, H., \& Or-Chen, K. (2015). Risk Factors for DSM-5 Posttraumatic Stress Disorder (PTSD) among Israeli Civilians during the 2014 Israel-Hamas War. Psychological Trauma: Theory, Research, and Policy, 8, 49-54. https://doi.org/10.1037/tra0000063

Greenberg, J., Pyszczynski, T., Burling, J., Simon, L., Solomon, S., Rosenblatt, A. et al. (1992). Why Do People Need Self-Esteem? Converging Evidence that Self-Esteem Serves and Anxiety-Buffering Function. Journal of Personality and Social Psychology, 63, 913-922. https://doi.org/10.1037/0022-3514.63.6.913

Hobfoll, S. E., Canetti-Nisim, D., Johnson, R. J., Palmieri, P. A., Varley, J. D., \& Galea, S. (2008). The Association of Exposure, Risk and Resiliency Factors with PTSD among Jews and Arabs Exposed to Repeated Acts of Terrorism in Israel. Journal of Traumatic Stress, 21, 9-21. https://doi.org/10.1002/jts.20307

Hu, L.-T., \& Bentler, P. M. (1999). Cutoff Criteria for Fit Indexes in Covariance Structure Analysis: Conventional Criteria versus New Alternatives. Structural Equation Modeling, 6, 1-55. https://doi.org/10.1080/10705519909540118

Kelly, T. A. (2007). The Role of Religion, Spirituality, and Faith-Based Community in Coping with Acts of Terrorism. In B. M. Bongar, L. M. Brown, L. E. Beutler, \& P. G. Zimbardo (Eds.), Psychology of Terrorism (pp. 137-152). Oxford, UK: Oxford University Press. https://doi.org/10.1093/med:psych/9780195172492.003.0010 
Lazarus, R, S., \& Folkman, F. (1984). Stress, Appraisal, and Coping (Chapter 4, pp. 47-93.). London: Springer Publishing Company.

Norris, F. H. (1992). Epidemiology of Trauma: Frequency and Impact of Different Potentially Traumatic Events on Different Demographic Groups. Journal of Consulting and Clinical Psychology, 60, 409-418. https://doi.org/10.1037/0022-006X.60.3.409

Norris, F. H., Friedman, M. J., Watson, P. J., Byrne, C. M., Diaz, E., \& Kaniasty, K. (2002). 60,000 Disaster Victims Speak: Part I. An Empirical Review of the Empirical Literature, 1981-2001. Psychiatry, 65, 207-239. https://doi.org/10.1521/psyc.65.3.207.20173

Nuttman-Shwartz, O., \& Dekel, R. (2007). Challenges for Students Working in a Shared Traumatic Reality. British Journal of Social Work, 37, 1247-1261.

https://doi.org/10.1093/bjsw/bcm 121

Pearlin, L. I., Menaghan, E. G., Lieberman, M. A., \& Mullan, J. T. (1981). The Stress Process. Journal of Health and Social Behavior, 22, 337-356.

https://doi.org/10.2307/2136676

Ron, P. (2008). The Relations between Work Stressors and Well-Being Among Nursing Assistants in Nursing Homes. Aging: Clinical Experimental Research, 20, 359-367. https://doi.org/10.1007/BF03324869

Ron, P. (2011). Post-Traumatic Stress Disorder among Three Generations Families in Times of War: A Comparison between Israeli Jewish and Arabs after the Second Lebanon War (2006) and Cast Lead Operation (2009). Traumatology, 20, 269-276.

https://doi.org/10.1037/h0099863

Ron, P. (2015a). From "Employer-Employee" to "Family of Choice": The Development of the Relationship between Philippine Worker Immigrants and Elderly Care Recipients. https://doi.org/10.4236/aar.2015.42007

Ron, P. (2015b). It's Not Their War: The Impact of Military Operations on Philippine Migrant Care Workers for Elderly People in Israel. Clinical Intervention in Aging, 10, 1053-1061. https://doi.org/10.2147/CIA.S77886

Ron, P. (2019). PTSD, ASD, Secondary-Traumatization, and Death-Anxiety among Civilians and Professionals as Outcomes of On-Going Wars, Terror Attacks and Military Operations: An Integrative View. Psychology Journal, 10, 1688-1710. https://doi.org/10.4236/psych.2019.1012111

Ron, P., \& Lowenstein, A. (1997). In-Service Training for Professionals and Para-Professionals in Residential Facilities. Gerontology, 78, 73-81 (In Hebrew).

Ron, P., \& Shamai, M. (2011). Challenging Secondary Traumatization and Burnout: The Impact of Ongoing National Terror on Social Workers. Journal of Social Work Research, 35, 36-45. https://doi.org/10.1093/swr/35.1.36

Ron, P., \& Shamai, M. (2013). The Impact of Ongoing National Terror on Nurses in Israel. Community Mental Health, 50, 354-361. https://doi.org/10.1007/s10597-013-9645-Z

Rosenberg, M. (1965). Society and the Adolescent Self-Image. Princeton, NJ: Princeton University Press. https://doi.org/10.1515/9781400876136

Saakvitne, K. W. (2002). Shared Trauma: The Therapist's Increased Vulnerability. Psychoanalytic Dialogues, 12, 443-449. https://doi.org/10.1080/10481881209348678

Shalev, A. Y., Tuval-Mashiach, R., Frenkiel-Fishman, S., Hadar, H., \& Eth, S. (2006). Psychological Responses to Continuous Terror: A Study of Two Communities in Israel. American Journal of Psychiatry, 163, 667-673.

https://doi.org/10.1176/ajp.2006.163.4.667

Sumer, N., Karanci, A. N., Berument, S. K., \& Gunes, H. (2005). Personal Resources, 
Coping Self-Efficacy, and Quake Exposure as Predictors of Psychological Distress Following the 1999 Earthquake in Turkey. Journal of Traumatic Stress, 18, 331-342.

https://doi.org/10.1002/jts.20032

Weinberg, M. (2017). Trauma and Social Support: The Association between Informal Social Support, Formal Social Support and Psychological Well-Being among Terror Attack Survivors. International Social Work, 60, 208-218.

https://doi.org/10.1177/0020872814564704

Weinberg, M., Besser, A., Campeas, M., Shvil, E., \& Neria, Y. (2012). Civilians Exposed to Terrorism and War Trauma in Israel: The Role of Intra- and Interpersonal Factors. In A. M. Columbus (Ed.), Advances in Psychology Research (Vol. 94, pp. 1-53). Hauppauge, NY: Nova Science Publishers.

Weinberg, M., Harel, H., Shamai, M., Or-Chen, K., Ron, P., \& Gil, S. (2017). War and Well-Being: The Association between Forgiveness, Social Support, PTSD and Well-Being during and Post-War. Journal of Social Work, 62, 1-8.

https://doi.org/10.1093/sw/swx043

Zimmet, G. D., Dahlin, N. W., Zimmet, S. G., \& Farley, K. G. (1988). The Multidimensional Scale of Perceived Social Support. Journal of Personality Assessment, 52, 30-41. https://doi.org/10.1207/s15327752jpa5201_2 